\title{
Karapandzic Flap for Functional \& Cosmetic Reconstruction of Lower Lip Cancer with Review of Literature
}

\author{
Sachin S Kadam ${ }^{1 *}$, Saurabh Phadke ${ }^{2}$, Tejaswini Kadam ${ }^{3}$ \\ ${ }^{1}$ Dept of Surgical Oncology, Currae Cancer \& Multispeciality Hospital, Mumbai, India \\ ${ }^{2}$ Dept of Surgical Oncolog, Terna Superspeciality Hospital, Nerul, New Mumbai, India \\ ${ }^{3}$ Dept of Ophthalmology, Conwest \& Jain Superspeciality Eye Hospital, Mumbai, India
}

*Corresponding Author: Sachin S Kadam, Dept of Surgical Oncology, Currae Cancer \& Multispecialty Hospital, Mumbai, India.

Received Date: September 13, 2021; Accepted Date: September 27, 2021; Published Date: October 08, 2021

Citation: Sachin S Kadam, S Phadke, T Kadam. (2021) Karapandzic Flap for Functional \& Cosmetic Reconstruction of Lower Lip Cancer with Review of Literature. J. Cancer Research and Cellular Therapeutics. 5(5); Doi: 10.31579/2640-1053/099

Copyright: () 2021 Sachin S Kadam, This is an open-access article distributed under the terms of the Creative Commons Attribution License, which permits unrestricted use, distribution, and reproduction in any medium, provided the original author and source are credited.

\begin{abstract}
The incidence and prevalence of lip and oral cavity cancer has increased over the last decade, worldwide and in India. It ranks at $1^{\text {st }}$ position in males in india, all ages, in 2020. Lips are essential organ of the body which carries dynamic role in facial expression, speech, sensuality, deglutition. Resection of central, large, lower lip cancer creates a more than $2 / 3^{\text {rd }}$ large defect. Covering of this defect with maintenance of oral competency is a difficult task for a treating surgeon. Number of techniques are described for covering of large lower lip defects. Out of these techniques, karapandzic flap is a successful, accepted, simple, easy to learn reconstructive procedure with good cosmetic results. It is a modification of Gillie's fan flap and it involves unilateral or bilateral full-thickness circumoral advancement-rotation flaps. The feature which distinguishes it from other techniques is preservation of neuro-vascular integrity, symmetry and oral competency. We are reporting a case of an elderly gentleman with large, central, lower lip cancer who underwent oncological resection with reconstruction by karapandzic flap technique.
\end{abstract}

Keywords: lip cancer; karapandzic flap; cosmesis; reconstructive surgery; squamous cell carcinoma

\section{Introduction}

Human lips are considered as the dynamic organ of the body as they are responsible for multiple functions like facial expression, articulation of speech, deglutition, and containment of salivary secretions. Lips are responsible for one's quality of life, self-esteem and facial appeal [1]. Squamous cell carcinoma of lip is considered as most common and aggressive malignancy. In $95 \%$ of cases lower lips are involved compared to only $5 \%$ involvement of upper lip [2]. Worldwide, number of new cases in 2020 , both sexes, all ages and number of death in 2020, both sexes, all ages were 3,77,713 and 1,77,757 respectively [3]. In India, lip and oral cavity cancer ranks at $1^{\text {st }}$ position in males, all ages with incidence $16.2 \%$ and $13.5 \%$ incidence in both sexes, all ages in 2020 [4]. Depending on the extent and depth of the tumor, the resection procedure works and depending on the defect of the lower lip, the reconstruction procedure will be planned. Full thickness loss of more than $1 / 2$ to $1 / 3^{\text {rd }}$ of lower lip poses a challenge to the treating surgeon as it's a difficult task to cover the defect with maintenance of commissure competence, cosmesis, symmetry and preservation of sensation.
Number of techniques are described and available for reconstruction of lower lip. Karapandzic flap is a technique for reconstruction of full thikness, large, centrally located defects of the lower lip and, to a lesser extent, the upper lip [5]. The technique involves unilateral or bilateral fullthickness circumoral advancement-rotation flaps [6]. The outstanding feature of this flap reconstruction technique is preservation of the neural and vascular structures which helps in maintaining oral competency and sensory function. We are reporting a case of an elderly gentleman with large, central, lower lip cancer who underwent oncological resection with reconstruction by karapandzic flap.

\section{Case Report}

A 51 year old gentleman with no co-morbidity with Eastern Cooperative Oncology Group Performance Status 1 (ECOG -PS 1) presented to our clinic with ulero-proliferative lesion over the lower lip for the last 4 months. He had an addiction of tobacco chewing and he used to consume it, 8-9 times per day for the last 30 years. Family history, past history, medical history and surgical history were not relevant. On clinical examination, an ulcero-proliferative growth of size $3 \times 3 \mathrm{~cm}$ was present over the lower lip at central region located at $2 \mathrm{~cm}$ left from right 
commissure and $1.5 \mathrm{~cm}$ right from left commissure [ Fig 2 ]. No other positive findings were noted in the oral cavity. Bilateral submandibular lymph nodes were palpable. He underwent CECT (Contrast Enhanced Computed Tomography) of oral cavity, neck and chest which was already advised by primary general practitioner. CECT was also suggestive of same findings with absent disease in the chest [Fig. 1]. We did wedge biopsy from the lesion which was indicative of squamous cell carcinoma.
Case was discussed in our institutional multidisciplinary tumor board and plan of upfront surgery was decided for him. As per board decision, we had planned surgery after getting fitness from physician and anesthesist. He underwent surgery with wide local excision of the lower lip lesion with bilateral selective neck dissection (Level I to IV) with reconstruction by karapandzic flap.

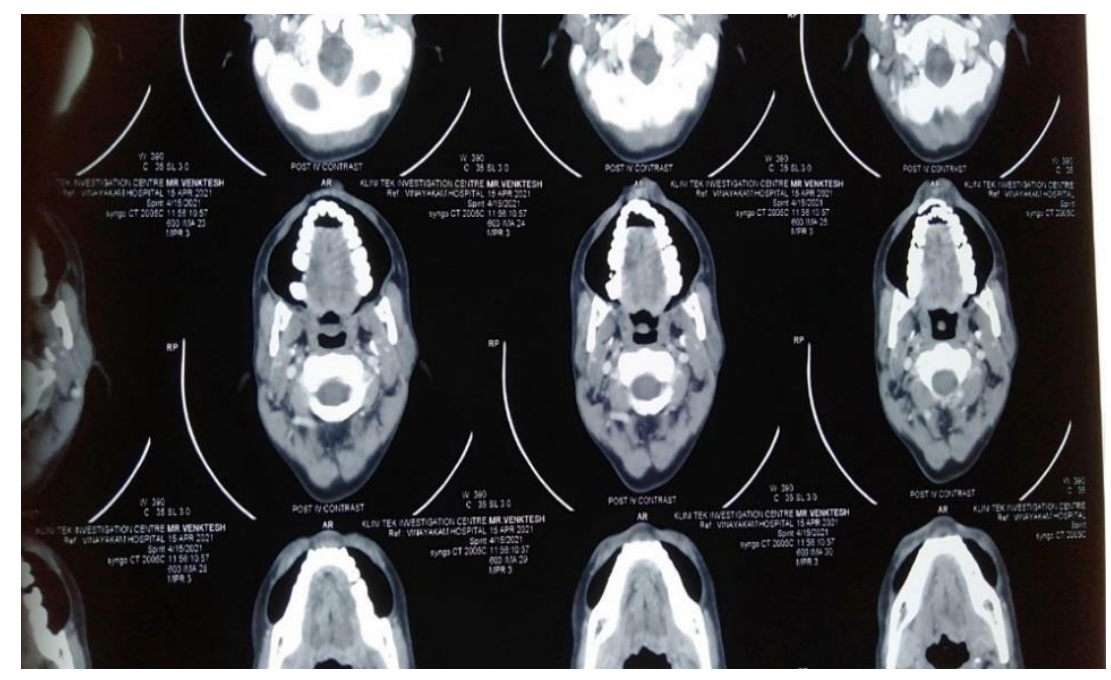

Figure 1: CECT of oral cavity

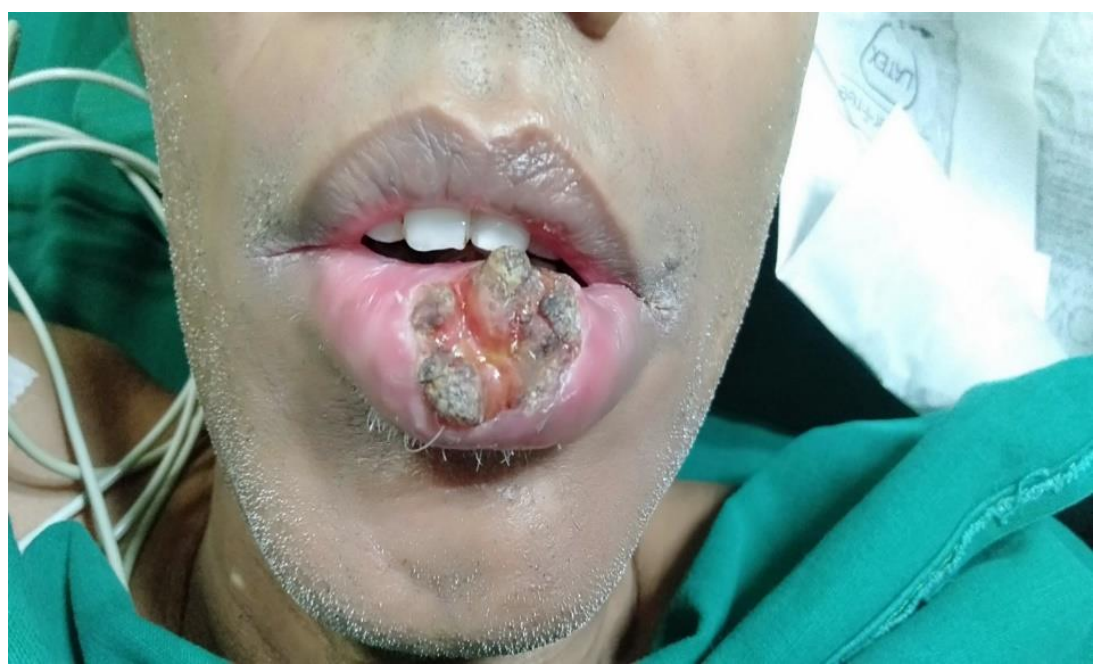

Figure 2: Central lower lip ulero-proliferative growth

After excision of the lesion [Fig. 3, 4], bilateral nasolabial folds are mobilised maintaining neurovascular structures. These mobilised full thickness circumoral advancement flaps are rotated and a new lower lip was reconstructed [Fig. 5,6]. Every care was taken to maintain the oral competency [Fig. 7]. Patient was started on oral feeding from postoperative day two. Postoperative course was uneventful and he was discharged on $5^{\text {th }}$ postoperative day. Final histopathology report was indicative of moderately differentiated squamous cell carcinoma with tumor size $3 \times 2.5 \times 1.5 \mathrm{~cm}$ and all margins were free from tumor except inner mucosal margin which was $0.3 \mathrm{~cm}$ away from the tumor ( close margin ) with no lymph node metastasis ( $0 / 47$ lymph nodes $)$. AJCC $8^{\text {th }}$ edition staging was p T2 pN0 pM0. Case was re-discussed in our board meeting for adjuvant treatment planning. Patient had been advised adjuvant radiation in view of close inner mucosal margin. However, patient didn't turn up for radiation. Hence, he had been advised close follow up as per our institutional follow up protocol. His swallowing function, speech was unaffected with no microstomia and no functional impairment. After completion of follow up period of one year post treatment [Fig. 8], he is still disease free. 


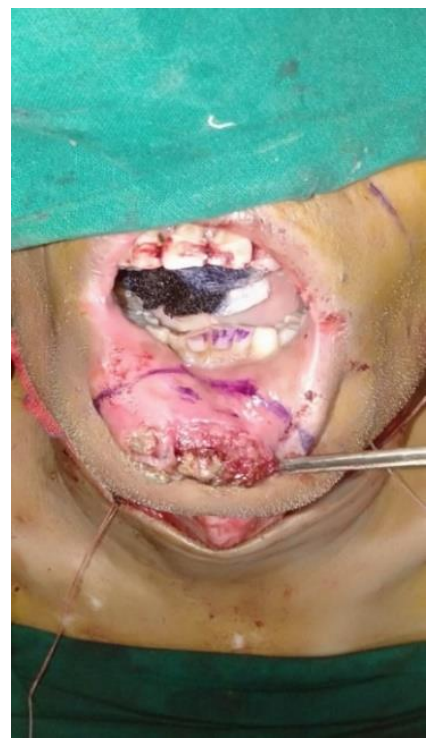

Figure 3: Incision marked before excision

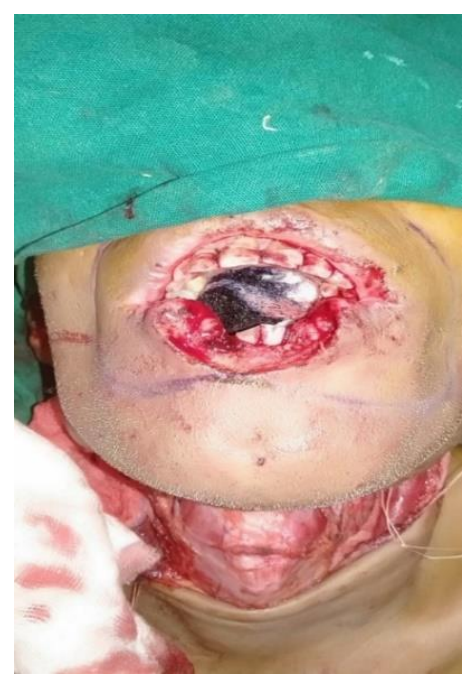

Figure 4: Post excision defect of the lower lip

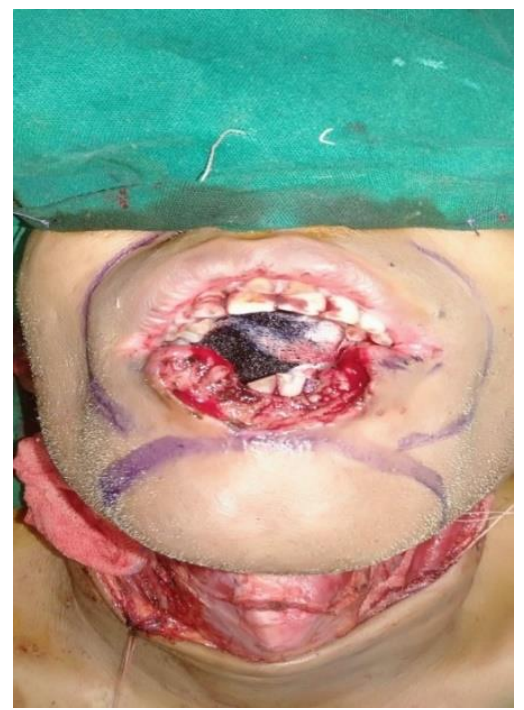

Figure 5: Marking at Naso-labial folds

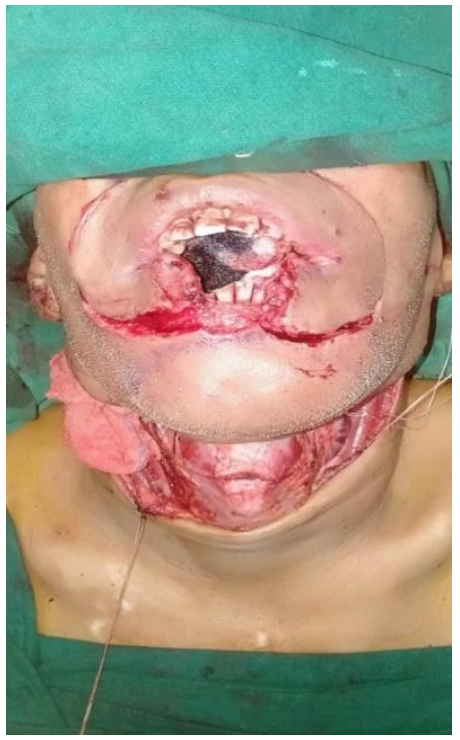

Figure 6: Bilateral flap harvesting

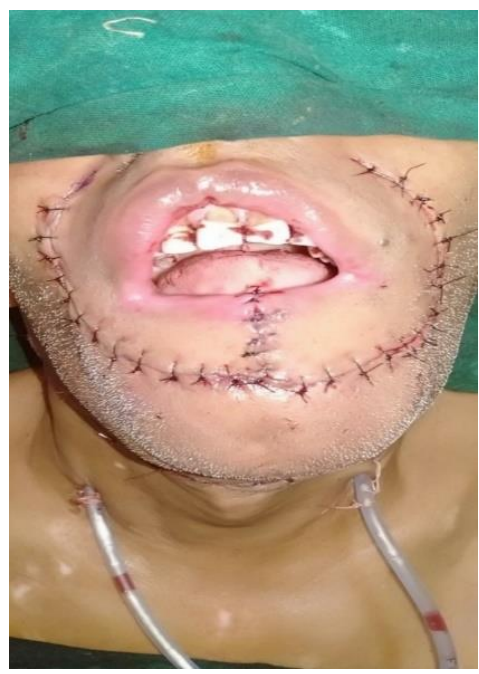

Figure 7: Approximation with new lower lip reconstruction

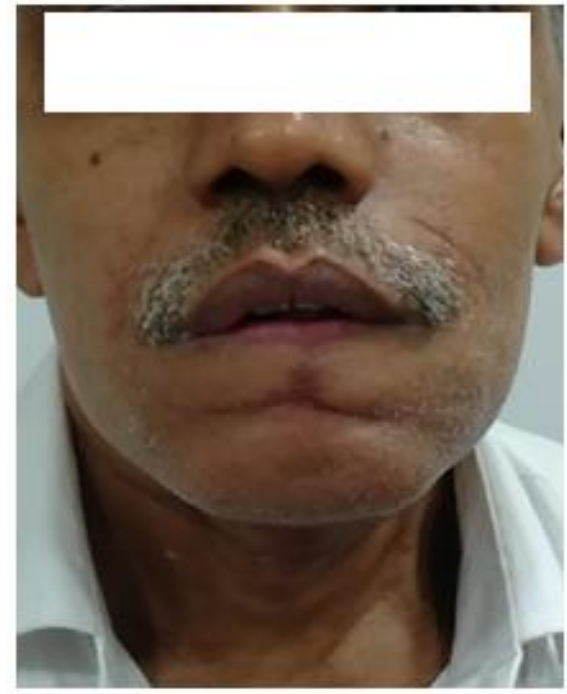

Figure 8: Follow up picture after 1 year 


\section{Discussion}

Lips are considered as an organ of expression, feeling and sensuality. Facial cosmesis will be affected if lips lost their functional integrity. Hence, it is very important for the reconstructive surgeon to maintain its normal form and shape. In 1768, Louis is the first person who described the method of $\mathrm{v}$-shaped excision of the lesion followed by primary closure [7]. Large size, full thickness defects of the lower lip requires a larger amount of tissue to cover up the defect which can provide desired functional outcome. Fujimori [8] and Nakajima et al [9] recommended some of the basic measures before selecting a reconstructive procedure -

1. Local flaps should be preferred with innervated muscle.

2. There should not be any microstomia in a newly reconstructed lip

3. All suture lines should be in natural facial creases.

4. The flaps should be large enough to contain whole elements of lip tissue.

The available techniques described for reconstruction of the lower lip with primary closure are " $Y$ ", " 'W', " $M$ ', or Z plasties for defects affecting less than one-third of the lip. For more extensive defects, the techniques available are the Abbe, Estlander, Gillies, Bernard-Burow flaps or combinations of these $[10,11]$. Webster-Bernard technique gives good results which creates new lower lip with medial advancement of the cheek tissue, however, significant scarring will be there in postoperative period [12].

Bakamjian [13] described the use of the tongue flap as a source of tissue in major lip reconstructions.

Mchug described reconstruction of large lip defects including the whole of the lower lip by using neurovascular island flap. The sensory function, muscular function and sphincter functions are maintained in this technique [14]. Rayner [15] described the technique of musculo-mucosal flaps from the cheeks. Johanson et al. [16] described the step ladder technique for lower lip reconstruction by mobilising lip tissue opposite to site of defect. Abbe or Estlander cross-lip transposition flaps are described for the reconstruction of defects of the lateral parts of the lower lip, however, their extent is limited to upper lip only [17].

Gillies and Millard [18] described a fan flap for reconstruction of the lower lip which is based on upper labial artery and it involves rotation of the naso-labial folds with advancement toward midline .However, this flap did not work in preserving neuro-vascular structures and it may result in formation of microstomia. Karapandzic [19] described a technique which is a modification of the Gillies fan flap and it was named as karapandzic flap. The main arterial supply of karapandzic flap is from the inferior labial artery, which is a branch of the facial artery. It provides numerous perforators through the orbicularis oris muscle to the overlying skin. Sensory nerve supply to the lower lip is from the mental nerve which is a terminal branch of inferior alveolar nerve which is in turn a branch of mandibular division of the trigeminal nerve. The principle feature of this flap is preservation of neuro-vascular structures, thus the competency of oral commissure and sensory and motor innervation are preserved with avoidance of additional transaction of orbicularis oris muscle [19]. Though the flap maintains the competency of oral commissure, in case of large lower lip defects, microstomia is unavoidable. However, it can be corrected with commissuroplasty [20]. In the indesx case, all dissection was carried out carefully with preserving neuro-vascular bundle and avoiding injury to orbicularis oris muscle with roation-advancement of naso-labial folds. Oral competency was maintained with maintenance of sensory and motor functions.

\section{Conclusion}

Karapandzic flap is a successful, simple, easy to learn technique for the reconstruction of central $2 / 3^{\text {rd }}$ of the lower lip with preservation of motor and sensory supply with maintaining oral competency and produces good cosmetic results.

\section{Disclosures}

Human subject: Informed consent was obtained from the patient for being included in the study.

Conflicts of interest: The authors declare that they have no conflict of interests.

Payment/services info: All authors have declared that no financial support was received from any organization for the submitted work.

Financial relationships: All authors have declared that they have no financial relationships at present or within the previous three years with any organizations that might have an interest in the submitted work.

Other relationships: All authors have declared that there are no other relationships or activities that could appear to have influenced the submitted work.

Availability of data and materials: Not applicable.

Consent for publication: An informed consent to publish this case was obtained from the patient.

Ethics approval and consent to participate: Not applicable.

\section{Clinical trial transparency: Not applicable}

\section{References}

1. Neligan PC. (2009). Strategies in lip reconstruction. Clin Plast Surg. 36(3): 477-85.

2. Dadhich AS, Shah S, Saluja H, Tandon P, More V. (2017). Karapandzic flap for esthetic and functional reconstruction of large defect of lower lip. Ann Maxillofac Surg. 7: 300-303.

3. Mazzola RF, Lupo G. (1984). Evolving concepts in lip reconstruction. Clin Plast Surg 11:583.

4. Renner GJ. (2007). Reconstruction of the lip (Chapter 19). In: Baker local flaps in facial reconstruction, 2nd edn. Elsevier, Philadelphia. 475-524.

5. Karapandzic M. (1974). Reconstruction of lip defects by local arterial flaps. Br J Plast Surg. 27: 93-97.

6. Fujimori R. (1980). "Gate flap" for the total reconstruction of the lower lip. Br J Plast Surg. 33: 340-345.

7. Nakajima T, Yoshimura Y, Kami T. (1984). Reconstruction of the lower lip with a fan-shaped flap based on the facial artery. Br J Plast Surg. 37:52-54.

8. Ishii LE, Byrne PJ. (2009). Lip reconstruction. Facial Plast Surg Clin N Am. 17(3):445-453.

9. NCCN. (2010). Clinical practice guidelines in oncology. Basal cell and squamous cell skin cancers, vol 1. NCCN, Washington.

10. Boutros S. (2007). Reconstruction of the lips (ch-36). In: Grabb and Smith's plastic surgery part-IV, 6th edn. William and Wilikins, Lipincott. 367-374.

11. Bakamjian V. (1964). Use of tongue flaps in lower lip reconstruction. Br J Plast Surg. 17:76-87.

12. Mchug M. (1977). Reconstruction of the lower lip using a neurovascular island flap. Br J Plast Surg. 30: 316-318.

13. Rayner CR, Arscott GD. (1987). A new method of resurfacing the lip. Br J Plast Surg. 40:454-458.

14. Johanson B, Aspelund E, Breine U, Holmstrom H. (1974). Surgical treatment of non-traumatic lower lip lesions with 
special reference to the step technique. scand J Plast Reconstr Surg. 8:232.

15. Abbe R. (1968). A new plastic operation for the relief of deformity due to double harelip (reprint from: medical Record 1898; 53:477). Plast Reconstr Surg. 42: 481-483.

16. Gillies H, Millard Jr. DR, eds. (1959). The Principles and art of plastic surgery. Boston: Little Brown.
17. Karapandzic M. (1974). Reconstruction of the lip defects by local arterial flaps. Brit J Plast Surg. 27(1): 93-97.

18. Closmann JJ, Pogrel MA, Schmidt BL. (2006). Reconstruction of perioral defects following resection for oral squamous cell carcinoma. J Oral Maxillofac Surg. 64:367-374.
This work is licensed under Creative

Commons Attribution 4.0 License

\section{To Submit Your Article Click Here: Submit Manuscript}

DOI: $10.31579 / 2640-1053 / 099$
Ready to submit your research? Choose Auctores and benefit from:

$>$ fast, convenient online submission

$>$ rigorous peer review by experienced research in your field

$>$ rapid publication on acceptance

$>$ authors retain copyrights

$>\quad$ unique DOI for all articles

$>$ immediate, unrestricted online access

At Auctores, research is always in progress.

Learn more auctoresonline.org/journals/cancer-research-and-cellulartherapeutics 